
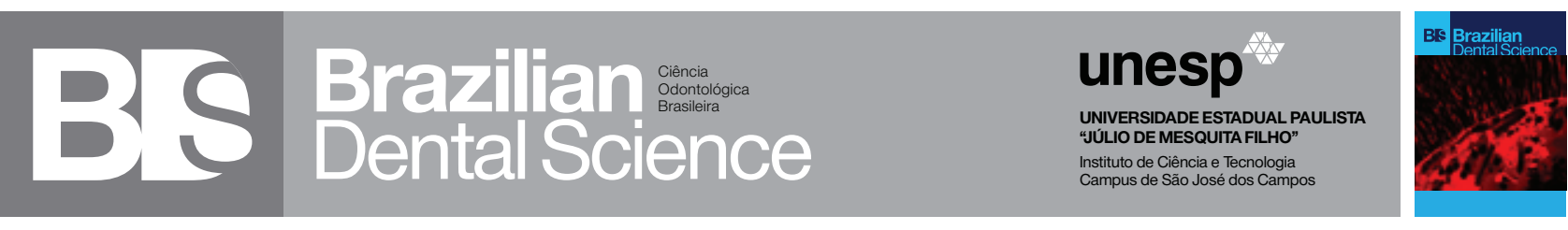

\title{
Occlusal Characteristics of Primary Dentition in Sudanese Children in Khartoum State
}

Características oclusais da dentição decídua em crianças Sudanesas do Estado de Khartoum

Amal H. Abu AFFAN ${ }^{1}$, Roa M. ABD-ALRAHMAN ${ }^{2}$

1 - Department of Orthodontic, Pedodontic and Preventive dentistry - Faculty of Dentistry - Khartoum University - Sudan.

2 - Ministry of Health - Khartoum - Sudan.

\section{ABSTRACT}

Background: Occlusal relationships in the primary dentition play an important role in the consequential final occlusion in permanent dentition. Therefore, good knowledge of occlusal relationships in children is essential for dental practitioners. Design: A descriptive, cross-sectional study done in randomly selected kindergartens in Khartoum State to determine the occlusal characteristics of primary dentition in a group of Sudanese children. Objective: To determine the occlusal characteristics feature of primary dentition in a group of Sudanese children. Methods: A sample of 381 children age 3-5 years old, randomly selected from kindergartens in Khartoum Stat. Clinical examination was done to all children fulfil the inclusion criteria in the teacher office and in natural day light. Prevalence of different types of terminal plane, types of primary canine relationship and spacing of the primary dentition were assessed. Results: Flush terminal plane was the most prevalent type of terminal plane $(72.2 \%)$. Class I canine relationship was the most common type of primary canine relationships (95\%). In the upper arch primate space and physiological spaces were present in $90.3 \%$ and $82.4 \%$ of the children, respectively. Nevertheless, the lower arch showed primate spaces in $70.1 \%$ and physiological spaces in $74.8 \%$ of the children. Conclusion: Large number of the examined children had flush terminal plane and spacing primary dentition that forecasts development of normal occlusion in their permanent dentition.

\section{KEYWORDS}

Dental occlusion; Primary dentition; Sudanese children

\section{RESUMO}

Introdução: As relações oclusais na dentição decídua desempenham um papel importante na oclusão final, na dentição permanente. Portanto, um bom conhecimento das relações oclusais em crianças é essencial para os cirurgiões-dentistas. Foi realizado um estudo descritivo, transversal, em creches selecionadas aleatoriamente no estado de Khartoum (Sudão) para determinar as características oclusais de dentição decídua em um grupo de crianças sudanesas . Objetivo: Determinar as características oclusais de dentição decídua em um grupo de crianças sudanesas. Métodos: Uma amostra de 381 crianças com idade entre 3 e 5 anos foram selecionados aleatoriamente a partir creches no estado de Khartoum. O exame clínico foi feito em todas as crianças cumpriram os critérios de inclusão, na sala dos professores sob luz natural do dia. Foram avaliadas a prevalência dos diferentes tipos de plano terminal, tipos de relação canina e espaçamento da dentição decídua. Resultados: $\mathrm{O}$ plano terminal em topo foi o tipo mais prevalente de plano terminal $(72,2 \%)$. A relação canina de Classe I foi o tipo mais comum de relacionamentos nos caninos decíduos ( $95 \%$ ). Os espaços primatas e fisiológicas nos arcos superiores estavam presentes em $90,3 \%$ e $82,4 \%$ das crianças, respectivamente. No entanto, os arcos inferiores mostraram espaços primatas em $70,1 \%$ e espaços fisiológicos em 74,8 $\%$ das crianças. Conclusão: Grande número de crianças examinadas tinham plano terminal em topo e espaçamento dentição decídua, o que pode predizer um desenvolvimento daoclusão normal na sua dentição permanente.

\section{PALAVRAS-CHAVE}

Oclusão dentária; Dentição decídua; Crianças sudanesas. 


\section{INTRODUCTION}

U nderstanding of the variations in terminal relationships of the deciduous second molars and their credence on the occlusal pattern of the eruption of the first permanent molars is essential for prevention and interception of malocclusions development.

The primary dentition is the stage of human dentition that starts from the eruption of the first primary tooth, usually the lower central incisor, and ends with the eruption of the first permanent molar, i.e. from around 6 months to 6 years of age. By $2 \frac{1}{2}$ years of age, primary dentition is usually complete and in full functioning position [1]. Primary teeth are important in a child's life as they help in mastication, in speech, contribute to aesthetics, preserve the integrity of the dental arches and finally guide the eruption of permanent teeth into their correct position [2].

The position of primary teeth usually become stable after complete eruption of the 20 primary teeth, usually when the child is 3 years old until the beginning of eruption of first permanent molars [3]. The size of tooth arch is altered by the eruption of first permanent molars around 5 to 6 years of age [4].

Two types of spaces are identified in the primary dentition, primate spaces mesial to maxillary canines and distal to mandibular canines [5], and physiological or developmental spaces present between the teeth, especially the incisors [6].

Spacing in the primary dentition have an important role to play later in the alignment of erupting permanent dentition and establishment of normal occlusion [5]. In the literature prevalence of spacing in the primary dentition varies between different populations and ethnic groups $[3,4,7]$. Absence of spaces in the primary dentition is an expression of imbalance between jaw and tooth size.

At the time of eruption of the first permanent molar, their initial occlusion is dependent on the terminal plane relationship of the primary second molars [8]. The occlusal relationships in the primary dentition are corresponding to those in the permanent dentition, but the descriptive terms are somewhat different. The most common relationship of the primary molar teeth is flush terminal plane results in Angel class I molar relationship. The distal step usually results in Angel class II molar relationship while lesser number of mesial step results in Angel class III molar relationship [5].

Preventive and interceptive measures in the primary and mixed dentitions are necessary for development of healthy and perfect occlusion in the permanent dentition. Therefore, the general dental practitioner should have a good knowledge about preventive and interceptive procedures and in case of existing problems, should interfere immediately to avoid the need of corrective treatment later on.

Evaluation of the development of occlusion in the primary dentition is essential to have an optimal occlusion in the permanent dentition and nowadays it is considered one of the most important objectives of pediatric dentistry. Enormous numbers of studies describing occlusal relationships and spacing in primary dentition were carried out among different populations in the world [5, 9-12]. Of these studies, some were reported among Arabian and African population [7, 9-12]. Consequently, the present study was carried out to evaluate the occlusal characteristics of the primary dentition in a sample of Sudanese children.

\section{MATERIAL \& METHODS}

A descriptive cross-sectional study carried out in randomly selected Kindergartens from Khartoum State. A total of 381 Sudanese children age 3 to 5 years old were examined. A stratified random sampling technique was used to calculate the sample size.

The inclusion criteria for selection of the sample were Sudanese children with complete fully-erupted sound primary dentition and 
absence of deleterious habits. All Children with carious teeth, cavities in inter proximal surface of anterior and/or posterior teeth, and first permanent molars erupted (partially or completely) were excluded from the study as well as children had developmental anomalies in tooth number, size, or shape as well as children whose parents refuse to sign the consent paper.

Written approvals had been obtained prior to carry out this study from the Research Committee of the University of Khartoum, the director of preschool education, the director of the targeted kindergarten and the parents of the participant child.

\section{METHODOLOGY}

Twenty seven kindergartens school from Khartoum State, were randomly selected. All children aged 3-5 years in the selected kindergarten were given written consents for their parents. Few days' later clinical examination had been carried out for 1037 children (whose parents agreed to participate in the study) in the day light using tell-show and do procedure. After that all children who fulfilled the inclusion criteria were registered, and then from each selected kindergarten 14 to 15 children were randomly selected for further examination. The total number of the selected children was 381 .

All clinical examination for the selected children was carried by the main investigator to avoid the inter examiner error in the teacher office while sitting the child in an upright position, the head rested on the back of the chair. The child was asked to bite in a maximal intercuspation with the jaws in centric relation taking into consideration the international standards of infection control protocol.

In the younger age group, the jaw had to be guided into the centric position. The terminal plane of the second primary molars was recorded, either flush terminal plane mesial or distal step. The primary canine relationships recorded as Class I, II or II, in addition the primate spaces and the physiological spaces had been recorded for each child.

Data were collected, summarized, cleaned and coded; then entered to the Statistical Package for Social Sciences (SPSS) program (version 17). Frequency tables and descriptive statistics were done. Chi-squire test was used to compare the proportions of different occlusal characteristics among different age groups. P-value of less than 0.05 was considered as significant.

\section{RESULTS}

The present study assessed the occlusal characteristics of the primary dentition of 381 Sudanese children aged 3 to 5 years, 191 boys (50.1\%) and 190 girls (49.9\%). The children were divided in two groups, group A 160 children (42\%) 3-4 years old and group B 221 children (58\%) 4-5 year old. Boys and girls were pooled in each age group, since there were no significant differences between them with respect to occlusion $(\mathrm{P}=0.078)$.

Table 1- The distribution of the terminal plane in 381 Sudanese children (\%)

\begin{tabular}{|ccccc}
\hline Type of terminal plane & $\begin{array}{c}\text { Group A } \\
\text { 3-4 years old }\end{array}$ & $\begin{array}{c}\text { Group B } \\
\text { 4-5years old }\end{array}$ & Total & P-value \\
\hline Bilateral flush terminal plane & $125(78.0 \%)$ & $150(67.9 \%)$ & $275(72.2 \%)$ & 0.082 \\
\hline Bilateral mesial step & $31(19.4 \%)$ & $55(24.9 \%)$ & $86(22.6 \%)$ & 0.067 \\
\hline Bilateral distal step & $2(1.3 \%)$ & $10(4.5 \%)$ & $12(3.1 \%)$ & 0.014 \\
\hline Different right/left terminal plane & $2(1.3 \%)$ & $6(2.7 \%)$ & $8(2.1 \%)$ & $381(100 \%)$ \\
\hline Total & $160(100 \%)$ & $221(100 \%)$ &
\end{tabular}


Table 2 - The distribution of the canine relationship in 381 sudanese children (\%)

\begin{tabular}{|ccccc}
\hline $\begin{array}{c}\text { Type of caniner } \\
\text { relationship }\end{array}$ & $\begin{array}{c}\text { Group A } \\
\text { 3-4 years old }\end{array}$ & $\begin{array}{c}\text { Group B } \\
\text { 3-5 years old }\end{array}$ & Total & P-value \\
\hline Bilateral class I & $154(96.3 \%)$ & $208(94.0 \%)$ & $362(95.0 \%)$ & 0.664 \\
\hline Bilateral class II & $5(3.1 \%)$ & $11(5.0 \%)$ & $16(4.2 \%)$ & 0.579 \\
\hline Bilateral class III & $0(0.0 \%)$ & $1(0.3 \%)$ & $1(0.3 \%)$ & 0.486 \\
\hline $\begin{array}{c}\text { Different right/left } \\
\text { canine relationship }\end{array}$ & $1(0.6 \%)$ & $1(0.5 \%)$ & $2(0.5 \%)$ & \\
\hline
\end{tabular}

Table 3 - Prevalence of the primate spaces in the upper and lower arch in 381 Sudanese children (\%)

\begin{tabular}{|c|c|c|c|c|}
\hline Primate space & $\begin{array}{l}\text { Group A } \\
\text { 3-4year }\end{array}$ & $\begin{array}{l}\text { Group B } \\
\text { 4-5 year }\end{array}$ & Total & P-value \\
\hline \multicolumn{5}{|c|}{ Upper arch } \\
\hline Present & 143(89.45\%) & $201(91 \%)$ & $344(90.3 \%)$ & 0.605 \\
\hline Notpresent & $17(10.6 \%)$ & $20(9.0 \%)$ & $37(9.7 \%)$ & \\
\hline Total & $160(100 \%)$ & $21(100 \%)$ & $381(100 \%)$ & \\
\hline \multicolumn{5}{|c|}{ Lower arch } \\
\hline Present & $127(79.4 \%)$ & $140(63.3 \%)$ & $267(70.1 \%)$ & 0.001 \\
\hline Not present & $33(20.6 \%)$ & $81(36.7 \%)$ & $114(29.9 \%)$ & \\
\hline Total & $160(100 \%)$ & $221(100 \%)$ & $381(100 \%)$ & \\
\hline
\end{tabular}

Table 4 - Prevalence of physiological space in the upper and lower arch in 381 children (\%)

\begin{tabular}{|c|c|c|c|c|}
\hline Physiological space & $\begin{array}{l}\text { Group A } \\
\text { 3-4 year }\end{array}$ & $\begin{array}{l}\text { Group B } \\
\text { 4-5 year }\end{array}$ & Total & P-value \\
\hline \multicolumn{5}{|c|}{ Upper arch } \\
\hline Present & $129(80.6 \%)$ & $185(83.7 \%)$ & $314(82.4 \%)$ & 0.496 \\
\hline Not present & $31(19.4 \%)$ & $36(16.3 \%)$ & $67(17.6 \%)$ & \\
\hline Total & $160(100 \%)$ & $221(100 \%)$ & $381(100 \%)$ & \\
\hline \multicolumn{5}{|c|}{ Lower arch } \\
\hline Present & $117(73.1 \%)$ & $168(76 \%)$ & $285(74.8 \%)$ & 0.551 \\
\hline Not present & $43(26.9 \%)$ & $53(24 \%)$ & $96(25.2 \%)$ & \\
\hline Total & $160(100 \%)$ & 221(100\%) & $381(100 \%)$ & \\
\hline
\end{tabular}


Table 1 showed that the flush terminal plane was very frequently occurring in the two studied age groups (72\%) and it more common in young age group. In contrast, a decreased prevalence of distal step was found in the younger age group. No statistically significant difference was found ( $P>0.05)$. On the other hand, distal step had elevated level with increasing age and the difference was statistically significant $(\mathrm{P}<$ 0.05).

Table 2 showed that Class: I was the most common canine relationship in both age groups (95.0\%) followed by Class: II (4.2\%). No statistically significant differences in canine relationship was found between the two age groups ( $\mathrm{P}>0.05)$.

The results showed that the spaced dentition is more frequent than closed dentition and spacing is more common in the maxillary arch than in the mandibular one in the two age groups.

Table 3 showed the distribution of the primate spaces in 381 children in both upper and lower arches. No statistically significant difference was found between the two age groups in maxillary arch in relation to primate space $(P=0.605)$. Whereas, in the lower arch the primate space was recorded less prevalent in the older age group which was statistically significant $(\mathrm{P}=0.001)$.

Table 4 showed that no statistically significant difference was observed between the two age groups in both upper and lower arch in relation to physiological group. $(\mathrm{P}=0.496) \&$ $(\mathrm{P}=0.551)$ respectively.

\section{DISCUSSION}

The present study was a cross sectional study planned to determine the types of terminal plane, canine relationship and spacing of the primary dentition in Sudanese children aged 3-5 years.

Many epidemiological studies have been carried out to document the occlusal characteristics of the primary dentition among various populations in the world $[3,5,10$, $12,13]$.

Occlusal characteristics of primary dentition in children are essential, it determine the future need for interceptive orthodontics treatment. Moreover, it would create a base line for further studies to find out changes in occlusal relationships with age. Lack of such information in Sudanese children was one of the objectives of this study.

It well known that the flush terminal plane is considered the most favorable occlusal relationship in children until the eruption of the first permanent molars [12]. On the other hand, other investigators $[8,14]$ reported that flush terminal plane or mesial step molar relationship are both normal.

In the current study, $72.2 \%$ of the children was reported with flush terminal plane molar relationship, the percentage was more common among younger age group (78\% group A and $67.9 \%$ group $B$ ) which is relatively similar to the results reported in the literature among different population [3, 7, 15-18].

The prevalence of flush terminal plane in the present study was lower in the 5 years age groups ad this finding coincide with BS Kumar and Hedge studies in Indian children [10, 19]. Slightly higher percentage of flush terminal plan was recorded among Turkish and Saudi children (88\% and $80 \%)$ respectively $[15,10]$.

Lower percentage of flush terminal plane, compare with the than present study had been reported among other population [11, 17, 18].

In the present study (22.6\%) of the Sudanese children were recorded with mesial step, which was the second prevalent type of terminal plane, and in harmony with previous studies [10, 11, 16-18]. Although, Abu Alhaija[9], Barbosa [20] and Anderson[21] reported mesial step as the most prevalent type of terminal planes which is in contrast with the present results. Furthermore, Yilmaz [15] reported that the mesial step was the 
least prevalent type of terminal plane among Turkish children.

The distal step in the present study was the least prevalent type of terminal plane and reported at $3.1 \%$ of Sudanese sample, which was comparable to the finding among different populations [7, 9-11, 16-18, 21]. A significant higher prevalence of distal step in the present study was recorded in the older age group, which contrasted the findings of Farsi et al. in Saudi children [10]. In controversy, results obtained by Sadakyio et.al[22] showed a high prevalence of distal step (67.9\%) in Brazilian children. While in Turkish children Yilmaz[15] reported that the distal step was more common than the mesial step which is contrasted with the present results.

The wide range of variations in the percentage of flush terminal plane, mesial and distal step may be attributed to the sample size, variation in the age group and ethnic background of the examined children.

In Jordanian children [9] the prevalence of asymmetrical right and left terminal plane was $11.6 \%$. While, lower percentage $(2.1 \%)$ of asymmetrical was observed in the present study. A possible explanation to the asymmetry may be related to variations in space distribution in each side.

The prevalence of class I canine relationship was as high as $95 \%$ in this study. Moreover, the prevalence of class II and class III canine were found as $4.2 \%$ and $0.3 \%$ of the children respectively. Similar results had been obtained by other authors among different populations $[9,10]$. However, much higher percent and of class II canine had been reported among British (45\%) and Jordanian (29\%) children [23, 9]. The differences in results could be attributed to difference in the sample sizes and the racial background of children in different countries.

In the present study class III canine was reported on one child in the age group 4-5 years, while it not present in the younger age. Whereas, studies carried out among Saudi and
Nigerian children showed that class III canine was more common than class II canine $[7,16]$. Asymmetrical right and left canine relationship was observed in $0.5 \%$ of the children which is much lower than those reported in Jordanian (10.3\%) and Nigerian (9\%) children [9,11].

Primate spaces in the present study were found in the majority $(90.3 \%)$ of the children in the upper jaw and less percentage (70.1\%) was reported in the lower jaw. These findings coincide with previous studies among Iranian, Jordanian, Egyptian, Nigerian and Indian children in which primate space was reported more prevalent in the maxilla than in the mandible $[3,4,7,11]$. However, in the present study the prevalence is a slight higher.

The results of this study indicated that the anterior spacing appears to be a common feature of the primary dentition among Sudanese children. The presence of physiological spacing in the maxillary and mandibular arches was $82.4 \%$ and $74.8 \%$ respectively, which is higher than the finding in Jordanian children $61 \cdot 8 \%$ and $61 \cdot 1 \%$ in the upper and lower arches, respectively. [9] However, generalized incisor spacing in Nigerian children was present in low percentage $37 \cdot 7 \%$ of the upper arches and in $44 \%$ of the lower arches [7].

Difference in the incidence of the primate and physiological spacing in the studies may be attributed to the genetic and environmental factors, ethnical background and difference in age of the examined children.

\section{CONCLUSIONS}

- Flush terminal plane is the most common type of terminal plane $(72.2 \%)$ followed by mesial step (22.6\%) and distal step (3.1\%).

- Class I canine relationship was the most prevalent one (95\%) followed by class II $(4.2 \%)$ and only one child had class III canine (0.3\%).

- Primate space was more frequent in the maxilla than in the mandible, vise versa the Physiological spacing more common in 
the mandible than in the maxilla and spaced dentition was more frequent than closed ones.

\section{RECOMMENDATIONS}

The present study aimed to provide an insight into the pattern of occlusal relationships in primary dentition of Sudanese children. As Sudan is a big country, future longitudinal studies for larger sample size and different age group including different states and more details in occlusal parameters investigation is recommended, to observe the changes that may occur during the transitional period of the dentition.

\section{REFERENCES}

1. Juneja T, Singh G. Development of Dentition. In: Singh G (Ed). Textbook of Orthodontics. New Delhi: Jaypee Brothers; 2007. p. 37-52.

2. King NM, Anthonappa RP, Itthagarun A The importance of the primary dentition to children-Part 1: consequences of not treating carious teeth. Hong Kong Practitioner. 2007;29(2):52-61.

3. Mahmoodian J, Afshar H, Hadjhashem M. Determination Of Primate Space On 4 To 5 Years Old Children Of Tehran's Kindergarten in 2000. J Dent Tehran University of Medical Sciences. 2004;1(1):21-6.

4. Joshi M, Makhija P. Some observations on spacing in the normal deciduous dentition of 100 Indian children from Gujarat. $\mathrm{Br} \mathrm{J}$ Orthod. 1984;11(2):75-9

5. Baume LJ. Physiological tooth migration and its significance for the development of occlusion. 1.The biogenetic cours of the deciduous dentition. J Dent Res. 1950;29(2):123-32.

6. Friel S. The development of ideal occlusion of the gum pad and the teeth. Am J Orthod. 1954;40:196-227.

7. Otuyemi $\mathrm{O}$, Sote $\mathrm{E}$, Isiekwe $\mathrm{M}$, Jones $\mathrm{S}$. Occlusal relationships and spacing or crowding of teeth in the dentitions of 3-4-year-old Nigerian children. Int J Paediatr Dent. 1997 Sep;7(3):155-60.

8. Bishara SE, Hoppens BJ, Jakobsen JR, FJ K. Changes in the molar relationship between the deciduous and permanent dentitions: a longitudinal study. Am J Orthod Dentofacial Orthop. 1988;93(1):19-28.
9. Abu Alhaija ES, Qudeimat MA. Occlusion and tooth/arch dimensions in the primary dentition of preschool Jordanian children. Int J Paediatr Dent. 2003 Jul;13(4):230-9.

10. Farsi NM, Salama FS. Characteristics of primary dentition occlusion in a group of Saudi children. Int J Paediatr Dent. 1996;6(4):253-9.

11. Onyeaso C, Sote E. A study of Malocculusion in the primary dentition in a population of Nigerian children. Nigerian Journal of Clinical Practice. 2002;5(1):52-56.

12. Clinch LM. An analysis of serial models between three and eight years of age. Dent Rec (London). 1951 Apr;71(4):61-72.

13. Nanda R S, Khan I, Anand R. Age changes in the occlusal pattern of deciduous dentition. J Dent Res 1973;52(2):221-224.

14. Onyeaso $\mathrm{CO}$, Isiekwe $\mathrm{MC}$. Occlusal changes from primary to mixed dentitions in Nigerian Children. Angle Orthod. 2008;78(1):64-69.

15. Yilmaz Y, Gurbuz T, Simsek S, Dalmis A. Primary canine and molar relationships in centric occlusion in three to six year-old Turkish children: a cross-sectional study. J Contemp Dent Pract. 2006;7(3): 59-66.

16. Baidas L. Occlusion characteristics of primary dentition by age in a sample of Saudi preschool children. Pakistan Oral Dent J. 2010;30(20).

17. Zakirulla M. Malocclusion in deciduous dentition of Saudi children: A cross-sectional study. Bangladesh J Med Sci. 2012;11(4):343-6.

18. Prado BN, Magalhães LdNC, Ferreira RI, Scavone-Junior H. Study of terminal relationships of the second molars in the deciduous dentition. Rev Odontol Univ Cid São Paulo. 2007;19(1):6-12.

19. Carvalho KL, Valença AMG. Prevalence of normal caracteristics of deciduous occlusion in 2-6 years old children. Pesqui bra odontopediatria Clin integr. 2004;4(2):113-20.

20. Barbosa CS, Di Nicoló R, Ursi WJS. Study of the prevalence of different types of terminal planes of primary second molars .Braz Dent Sci. 2010;3(1):41-8.

21. Anderson AA. Occlusal development in children of african american descent. Angle Orthod. 2006;76(5):817-23.

22. Sadakyio CA, Degan VV, P Neto G, Rontani RMP. Malocclusion prevalence in Brazilian preschoolers from Piracicaba - SP. Braz Dent Sci. 2010;7(2):92-9.

23. Foster TD, Hamilton MC. Occlusion in the primary dentition. Study of children at 2 and one-half to 3 years of age. Br Dent J. 1969 21;126(2):76-9.

\section{Associate Professor Amal H. Abu Affan} (Corresponding address)

Head department of Orthodontic, Pedodontic and Preventive dentistry, Faculty of Dentistry, University of Khartoum, Sudan Date submitted: 2013 Nov 16 E-mail: amalabuaffan@yahoo.com Accept submission: 2014 Jan 13 